\title{
Evaluation of drying technologies for retention of physical quality and antioxidants in asparagus (Asparagus officinalis, L.)
}

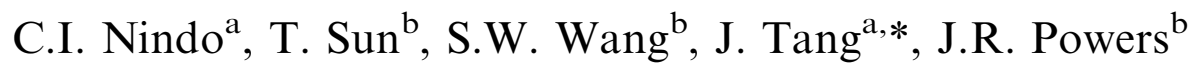 \\ ${ }^{a}$ Department of Biological Systems Engineering, Washington State University, 213 L J Smith Hall, Pullman, WA 99164 6120, USA \\ ${ }^{\mathrm{b}}$ Department of Food Science and Human Nutrition, Washington State University, Pullman, WA 99164, USA
}

Received 30 September 2002; accepted 21 January 2003

\begin{abstract}
The objective of this research is to evaluate drying methods that have the potential of adding value to green asparagus especially for use as ingredient in instant foods or as a nutraceutical product. Five drying methods were used: namely, tray drying (TD), spouted bed (SB) drying, combined microwave and spouted bed drying (MWSB), Refractance Window (RW) drying and freezedrying. Asparagus spears with diameters between 9 and $12 \mathrm{~mm}$ were blanched in $85^{\circ} \mathrm{C}$ water-bath for $3 \mathrm{~min}$, sliced into $2-4 \mathrm{~mm}$ thickness (or pureed for RW drying), then dried to moisture content less than $0.1 \mathrm{db}$. MWSB drying produced asparagus particles with good rehydration and color characteristics, and was the fastest among the methods where heated air was used. When using MWSB drying, the power level of $2 \mathrm{~W} / \mathrm{g}$ and $60^{\circ} \mathrm{C}$ heated air resulted in highest retention of total antioxidant activity (TAA). TAA of asparagus was enhanced after RW and freeze-drying, with the TAA values being significantly higher than for heated air-drying methods. In all cases, the tip portion of asparagus retained more TAA after drying than either middle or basal parts. The highest amount of ascorbic acid was retained in the product after RW drying, followed by freeze-drying, MWSB and SB drying. TD resulted in the least retention of ascorbic acid.
\end{abstract}

(C) 2003 Swiss Society of Food Science and Technology. Published by Elsevier Science Ltd. All rights reserved.

Keywords: Drying technologies; Asparagus; Rehydration ratio; Ascorbic acid; Antioxidants

\section{Introduction}

Most of the asparagus (Asparagus officinalis, L.) produced in the state of Washington is canned or fresh packed before shipping to grocery stores. About 2-3\% of total production is processed into pickled products. Some small and medium enterprises engage in other conversion processes, such as juice extraction. Thousands of tons of high-quality asparagus parts are usually rejected as trims during canning and fresh packing operations. The large amount of byproducts from the canning process is partly attributed to the industry's requirement that asparagus spears be trimmed to fit certain can sizes and not necessarily that the trims are of

Abbreviations: AA, ascorbic acid; FD, freeze-drying; MC, moisture content; MW, microwave; MWSB, microwave spouted bed; RW, Refractance Window ${ }^{\mathrm{TM}}$; SB, spouted bed; TAA, total antioxidant activity; TD, tray drying.

*Corresponding author. Tel.: + 1-509-335-2140; fax: + 1-509-3352722.

E-mail address: jtang@mail.wsu.edu (J. Tang). low quality. Some processing plants make an effort at increasing recovery rate by sorting the trimmed portions for canning as cuts. Apart from the low recovery rate problem, the Washington asparagus industry is facing major competition due to low tariff imports of fresh asparagus (Calvin \& Cook, 1997; USGAO, 2001).

Asparagus contains flavonoids (mainly rutin) and other phenolic compounds, which possess strong antioxidant properties (Makris \& Rossiter, 2001). Vinson, Hao, Su, and Zubik (1998) analysed 23 vegetables commonly consumed in the United States and found that asparagus is the first in terms of total quality and quantity of antioxidants. They also ranked asparagus fourth in terms of total phenols content. Although asparagus has this immense health benefit, the results given by Vinson et al. (1998) show that per capita consumption of asparagus is still small compared to the other vegetables. To increase its consumption and the returns to farmers and processors, it is important to take advantage of the health benefits of asparagus by investigating some alternative value-adding processing 
methods. With novel drying methods like Refractance Window (RW) technology and combined microwave and spouted bed (MWSB), increased retention of the beneficial bioactive compounds in the dried asparagus can be achieved. In most Asian countries, including Japan and China, dehydrated vegetables are popularly used as ingredients in soups and are usually included in foods such as instant noodles. This means that a large market exists for dehydrated asparagus.

Similar to other vegetables, changes in color, chemical and textural attributes of asparagus occur during thermal treatments such as canning, pasteurization and drying. For example, the degradation of ascorbic acid and change of the green color of asparagus spear surface during thermal treatments have been shown to follow first-order reaction kinetics (Esteve, Frigola, Martoreli, \& Rodrigo, 1998; Lau, Tang, \& Swanson, 2000). Strahm and Flores (1994) and Strahm, Flores, and Chung (1995) also studied drying and color kinetics of lowgrade green asparagus during heated air-drying and observed similar trends. More recently, Krokida, Maroulis, and Saravakos (2001) reviewed the effect of hot air, vacuum, microwave, freeze- and osmotic-drying on the color of dehydrated agricultural commodities and stated that the browning of fruits and vegetables during drying is due to both enzymatic and nonenzymatic browning reactions. Browning is usually a negative quality attribute, but other studies show that overall antioxidant properties of certain foods may be enhanced due to formation of melanoidins during the advanced steps of the Maillard reaction (Anese, Manzocco, Nicoli, \& Lerici, 1999a; Anese, Nicoli, Massini, \& Lerici, 1999b; Nicoli, Anese, Parpinel, Franceschi, \& Lerici, 1997).

The time it takes to reconstitute a dried vegetable and appearance of the vegetable are two important physical factors that need special attention when designing, selecting or evaluating a given drying process. The ability of food products to reconstitute in piece form, such as sliced or diced vegetables, depends primarily on the internal structure of the dried pieces and the extent to which the water-holding components (e.g. proteins and starch) have been damaged during drying (Brennan, Butters, Cowell, \& Lilly, 1990). With hot-air-drying, higher drying rate at the initial stage may cause case hardening of the product surface and result in loss of ability for fast reconstitution. Somogyi and Luh (1986) reported a study on the effect of drying methods on quality of dehydrated green asparagus in which it was observed that freeze-dried green asparagus with hot water blanching was faster in reconstitution and more tender in texture than the hot-air-dried product. Drying of vegetables with hot air usually results in considerable shrinkage and formation of dense structure. Since microwave heating targets the water at the core of particulate products that generates relatively high internal vapor pressure, it is possible to produce a porous product (Feng, Tang, Cavalieri, \& Plump, 2001). Such a porous product reconstitutes much faster than the ones obtained by using conventional hot-air-drying. Feng and Tang (1998) reported low bulk densities resulting from the puffing effect when diced apples were dried in a microwave spouted bed. In a microwave puffing study using carrots Torringa, Van Dijk, and Bartels (1996) concluded that drying at higher microwave power densities gives much shorter drying times, reduced shrinkage, higher open-pore porosity and improved rehydration characteristics in comparison with a standard convective drying process. Nijhuis et al. (1998) also observed that the more homogeneous dehydration and the developed internal pressure with microwaves result in less reduction in the volume of microwave-dried products.

Ascorbic acid (Vitamin C) is an important nutrient in vegetables. It is more sensitive to heat, oxygen and light than most other components in asparagus such as vitamin A, E or some phenolic compounds. Ascorbic acid can also act as a synergist with tocopherols by regenerating or restoring their antioxidant properties (Yanishlieva-Maslarova, 2001). Depending on the type of process, product physical properties, and the time-temperature regimes used, thermal energy can cause varying degrees of loss of vitamin $\mathrm{C}$ during drying of green vegetables. Generally, if a process for drying vegetables takes place at a low temperature and within a short time, relatively high retention of the heat-labile vitamin $\mathrm{C}$ is expected. This is the reason we used ascorbic content in asparagus as a marker to find out the best drying method for retaining nutritional quality of dried asparagus. Although antioxidants are usually not damaged during drying (Pokorny \& Schmidt, 2001), it is important to know the retention of total antioxidant activity (TAA) after a particular drying operation.

The objective of this research is to evaluate effective drying methods that might produce high-quality asparagus. Drying rate, rehydration ratio, color, and retention of TAA and ascorbic acid were used as indices for comparison. We compared five different methods: namely, tray, spouted bed (SB), MWSB, RW and freeze-drying. Tray drying (TD) is commonly used for drying of vegetables, and it was chosen because of its simplicity and low cost. TD is also often used in R\&D laboratories to simulate industrial tunnel or conveyor dryers. Freeze-drying on the other hand is expensive, but quality of product is usually high. SB and MWSB drying (for food particles), and RW drying (for food flakes or powders) fall in between and have been shown to produce high-quality dried foods (Feng, Tang, Mattinson, \& Fellman, 1999; Abonyi et al., 2002). Our ultimate intention is to use the dried asparagus either as ingredient in instant soups or for further processing into a nutraceutical product. 


\section{Materials and methods}

Fresh green asparagus used for the tests were obtained from farmers' fields in Central Washington. The spears were stored in a cool box with ice and transported on the day of harvest to Washington State University. The spears were blanched in a water-bath maintained at $85^{\circ} \mathrm{C}$ for $3 \mathrm{~min}$ and immediately cooled in ice water $\left(0-2^{\circ} \mathrm{C}\right)$ for equal time. Spot test for peroxidase activity was conducted to determine adequacy of the blanching process. After blanching, the water adhering on the surfaces was removed with paper towel after which the portions selected for drying were cut into $2-4 \mathrm{~mm}$ slices. These were then dried using a laboratory microwave spouted bed dryer (Fig. 1), a pilot scale tray dryer (Armfield Limited, Ringwood, Hampshire, UK) similar to that described by Maskan (2000), or a freeze dryer (Freeze Mobile 24, Vertis Company, Inc., Gardiner, NY, USA). In each experiment $100 \mathrm{~g}$ of blanched asparagus was used; and for TD the $100 \mathrm{~g}$ of sliced asparagus was placed on four trays $(28 \mathrm{~cm} \times 18 \mathrm{~cm})$ arranged in a vertical stack. Moisture content of asparagus before and after drying was determined by the vacuum oven method (AOAC, 1995).

During MWSB drying, asparagus pieces were placed in a spout funnel made of a special microwavetransparent plastic material, and then fluidized with heated air at $50^{\circ} \mathrm{C}, 60^{\circ} \mathrm{C}$, and $70^{\circ} \mathrm{C}$. A detailed description of this system is provided in Feng et al. (2001). Microwave energy, supplied by a $1.5 \mathrm{~kW}$ magnetron operating at $2450 \mathrm{MHz}$, was applied to the asparagus at 0,2 , and $4 \mathrm{~W} / \mathrm{g}$ of wet material. The power level of $0 \mathrm{~W} / \mathrm{g}$ represented SB drying. These experiments were repeated three times. By using known moisture content and weight of asparagus at the start of each experiment and periodically taking the sample weight, the drying end point was determined when moisture content had fallen to less than $0.1(\mathrm{db})$.

Asparagus was also dried from a puree using a new thin-film drying method called Refractance Window ${ }^{\mathrm{TM}}$ drying. This drying system utilizes circulating water at 95- $-97^{\circ} \mathrm{C}$ as a means to carry thermal energy to materials to be dehydrated. In operation, a pureed product is spread as a thin film on a transparent conveyor belt that moves over hot water circulating in a trough (Fig. 2). Thermal energy from the circulating hot water is transferred through the belt to remove moisture in the product. The actual product temperature is usually between $70^{\circ} \mathrm{C}$ and $80^{\circ} \mathrm{C}$ (Abonyi et al., 2002). Detailed information about the general engineering performance of this system is provided in Abonyi et al. (2002). In our study, prior to RW drying, fresh asparagus spears were washed, blanched, divided into tip, middle and bottom portions and shipped in a cooler box by priority overnight delivery to MCD Technologies Inc. (Tacoma, WA). The fresh samples were pureed in a blender (Oster
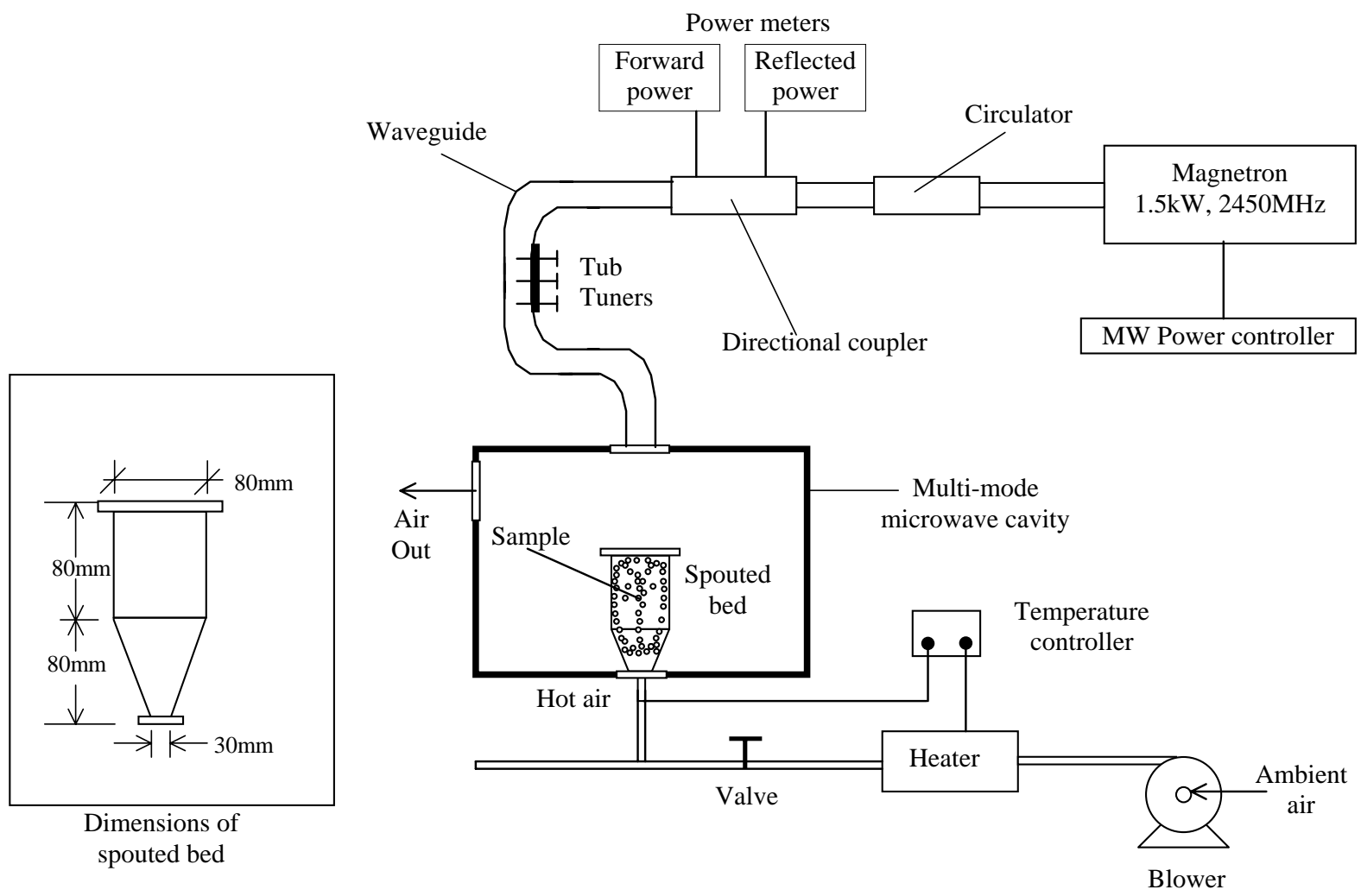

Fig. 1. Schematic of combined microwave and spouted bed drying (MWSB) drying system. 


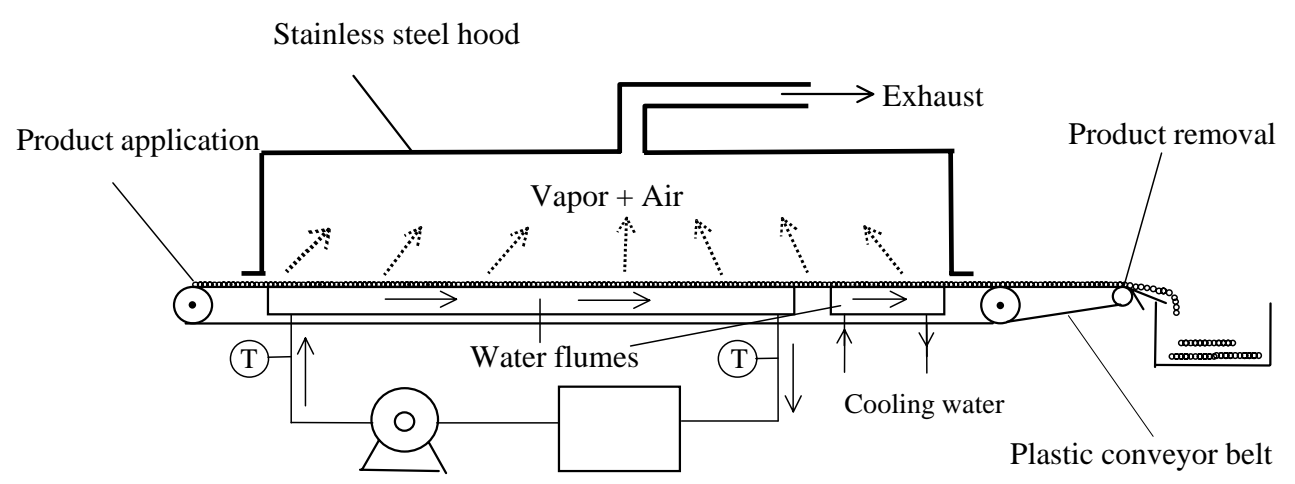

Hot water pump Water tank \& heater

Fig. 2. Schematic of pilot scale Refractance Window ${ }^{\mathrm{TM}}$ drying system (adapted from Abonyi et al., 2002).

Model SV, John Oster Mfg. Co., Milwaukee, WI, USA) that was nitrogen flushed during each use. The blender was modified by drilling a hole in the cover for inserting a hose from a regulated nitrogen bottle thereby flushing most oxygen from the blender jar while the samples were pureed. To facilitate spraying of the puree onto the conveyor belt for drying, a predetermined amount of distilled water was added during blending thereby increasing the water content from 11.5 to about 21.0 (db). The residence time for the puree on the belt was $4.5 \mathrm{~min}$. The dried product $(<0.1 \mathrm{MC} \mathrm{db})$ was packaged in sealed aluminum bags, flushed with a drop of liquid nitrogen and shipped to Washington State University for analysis.

In summary, the drying methods and test conditions were:

- SB using air temperatures at $50^{\circ} \mathrm{C}, 60^{\circ} \mathrm{C}$ and $70^{\circ} \mathrm{C}$.

- Combination of MWSB drying using air temperatures at $50^{\circ} \mathrm{C}, 60^{\circ} \mathrm{C}$ and $70^{\circ} \mathrm{C}$. Microwave (MW) energy was applied at 2 and $4 \mathrm{~W} / \mathrm{g}$ (wet basis).

- TD at air temperatures of $50^{\circ} \mathrm{C}, 60^{\circ} \mathrm{C}$, and $70^{\circ} \mathrm{C}$.

- Freeze-drying (heating plate temp. $20^{\circ} \mathrm{C}$; condenser temp. $-64^{\circ} \mathrm{C}$; abs. pressure $3.3 \mathrm{kPa}$ ).

- RW drying from asparagus puree (heating water temperature, $95^{\circ} \mathrm{C}$ ).

The following parameters were used for evaluating the drying results:

(1) Drying rate, (2) L, a*, b* color values, (3) rehydration ratio, (4) TAA, and (5) ascorbic acid content.

\subsection{Physical analysis}

Rehydration ratio of slices was determined using $2 \mathrm{~g}$ samples dipped into water maintained at $70^{\circ} \mathrm{C}$ in a water-bath and the weight of asparagus was measured after soaking for $5,10,15,20$, and $30 \mathrm{~min}$. The amount of water absorbed during soaking divided by the mass of dry solids gave the rehydration ratio. Color was measured using Minolta Chroma CR-200 color meter (Minolta Co., Osaka, Japan). The color parameter values of lightness (L), greenness/redness $\left(-/+\mathrm{a}^{*}\right)$, and blueness/yellowness $\left(-/+b^{*}\right)$ were recorded for each product. The ratio $b^{*} / a^{*}$, which is a measure of hue, was calculated and plotted against the lightness $\mathrm{L}$ for easy comparison. The deviation from the raw material color was represented as $\Delta E^{*}$ and calculated as $\sqrt{\left\{\left(\mathrm{L}-\mathrm{L}_{0}\right)^{2}+\left(\mathrm{a}^{*}-\mathrm{a}_{0}\right)^{2}+\left(\mathrm{b}^{*}-\mathrm{b}_{0}\right)^{2}\right\}}$, where $\mathrm{L}_{0}, \mathrm{a}_{0}$ and $b_{0}$ are the color parameters of blanched asparagus before drying.

\subsection{Analysis of total antioxidant and ascorbic acid}

To evaluate the effect of the drying methods on retention of ascorbic acid and total antioxidants, two sets of drying experiments were conducted: one with sliced whole spears, and another after cutting the spears into three sections (apical, middle and basal parts). The three sections were cut as follows: apical portion (0$7 \mathrm{~cm})$, middle $(7-14 \mathrm{~cm})$, and basal $(7-21 \mathrm{~cm})$. The sections were then dried by various methods as previously described and ground before extraction. TAA was measured by ABTS/HRP decoloration method (Miller, Diplock, \& Rice-evans, 1995; Cano, Hernández-Ruíz, García-Cárnovas, Acosta, \& Arnao, 1998). The assay estimates the relative ability of the antioxidant substance to scavenge the radical cation of 3-ethylbenzothiazoline-6-sulfonate $\left(\mathrm{ABTS}^{\cdot+}\right)$ compared to a standard antioxidant (Trolox) using a doseresponse curve. The hydrophilic antioxidant activity of dry asparagus and fresh asparagus was measured. Dried and fresh asparagus were ground for $50 \mathrm{~s}$ using a coffee grinder before extraction. Ground asparagus $(0.20 \mathrm{~g}$ for dried asparagus and $2.00 \mathrm{~g}$ for fresh asparagus) were added to $28 \mathrm{ml} 50 \mathrm{mM}$ MES (pH 6.0) buffer, mixed by vortexing for $20 \mathrm{~s}$, and centrifuged at $35,000 \mathrm{~g}$ for $20 \mathrm{~min}$ at $4{ }^{\circ} \mathrm{C}$. The MES buffer supernatant was used for measuring hydrophilic antioxidant activity. For 
hydrophilic antioxidant activity, the reaction mixture contained $200 \mu \mathrm{L} 15 \mathrm{mM}$ aqueous ABTS, $80 \mu \mathrm{L} 1.0 \mathrm{mM}$ $\mathrm{H}_{2} \mathrm{O}_{2}, 10 \mu \mathrm{L} 3.3$ unit $/ \mu \mathrm{l}$ HRP and $1660 \mu \mathrm{L} 50 \mathrm{mM}$ sodium phosphate buffer ( $\mathrm{pH}$ 7.5). The reaction was monitored at $734 \mathrm{~nm}$ until stable absorbance was obtained. Fifty microliters of extract from the MES phase was added to the reaction medium and the decrease in absorbance, which is proportional to the ABTS $^{*}$ quenched, was determined after $5 \mathrm{~min}$. The standard for TAA was $1 \mathrm{mM}$ Trolox in MES buffer for hydrophilic antioxidant activity (we do not report any hydrophobic antioxidant data).

Ascorbic acid in asparagus was determined according to AOAC official method (AOAC, 1995). Half a gram of dried asparagus ( $5 \mathrm{~g}$ for fresh) was blended with $50 \mathrm{~mL}$ of metaphosphoric-acetic acid solution to extract ascorbic acid. The mixture was centrifuged and then the supernatant was taken and transferred to a volumetric flask. This was rapidly titrated with indophenol solution until light distinct rose pink color persisted for more than $5 \mathrm{~s}$. Three replicates of each sample were analysed.

\section{Results and discussion}

\subsection{Drying kinetics}

Fig. 3a shows the change of moisture content versus residence time during $\mathrm{TD}$ at $60^{\circ} \mathrm{C}$ air temperature, $\mathrm{SB}$ drying at $60^{\circ} \mathrm{C}$, and MWSB drying at 2 and $4 \mathrm{~W} / \mathrm{g}$ of power input levels with a fluidization temperature of $60^{\circ} \mathrm{C}$. To reduce the moisture content from 11.5 to just below $0.1 \mathrm{db}$, TD took $3.5 \mathrm{~h}$, while combined MWSB drying at a power level of $4 \mathrm{~W} / \mathrm{g}$ took only $0.6 \mathrm{~h}$. At a microwave power level of $4 \mathrm{~W} / \mathrm{g}$, the drying rate was 6.0 , 2.8, and 1.7 times faster than TD, SB, and MWSB drying at $2 \mathrm{~W} / \mathrm{g}$, respectively (Fig. 3b). This was due to

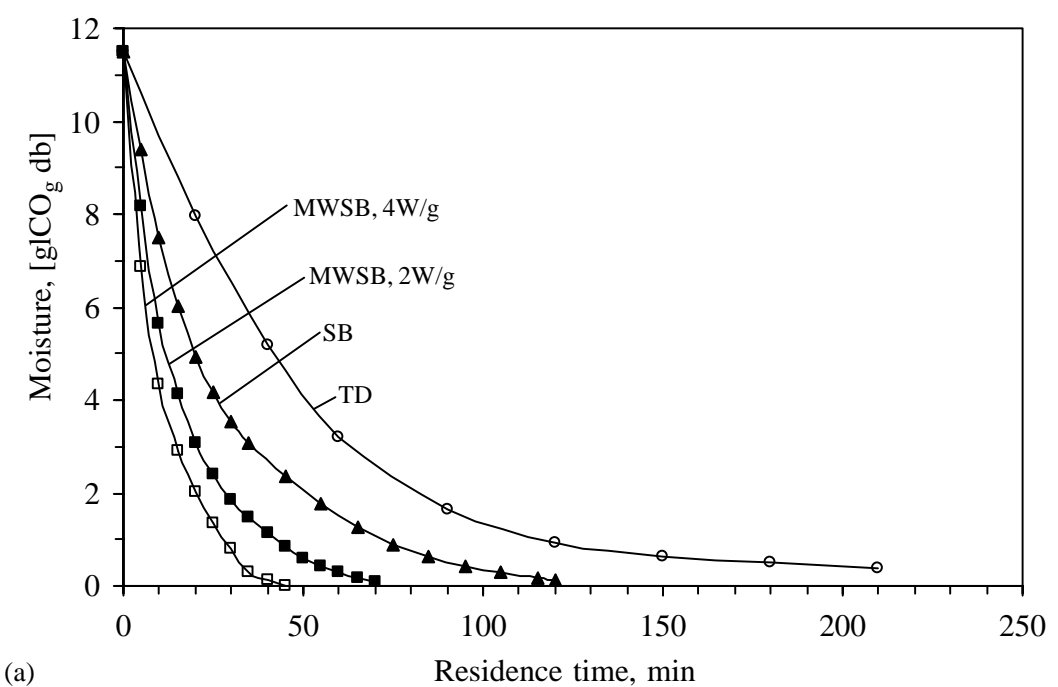

(a)

Residence time, min

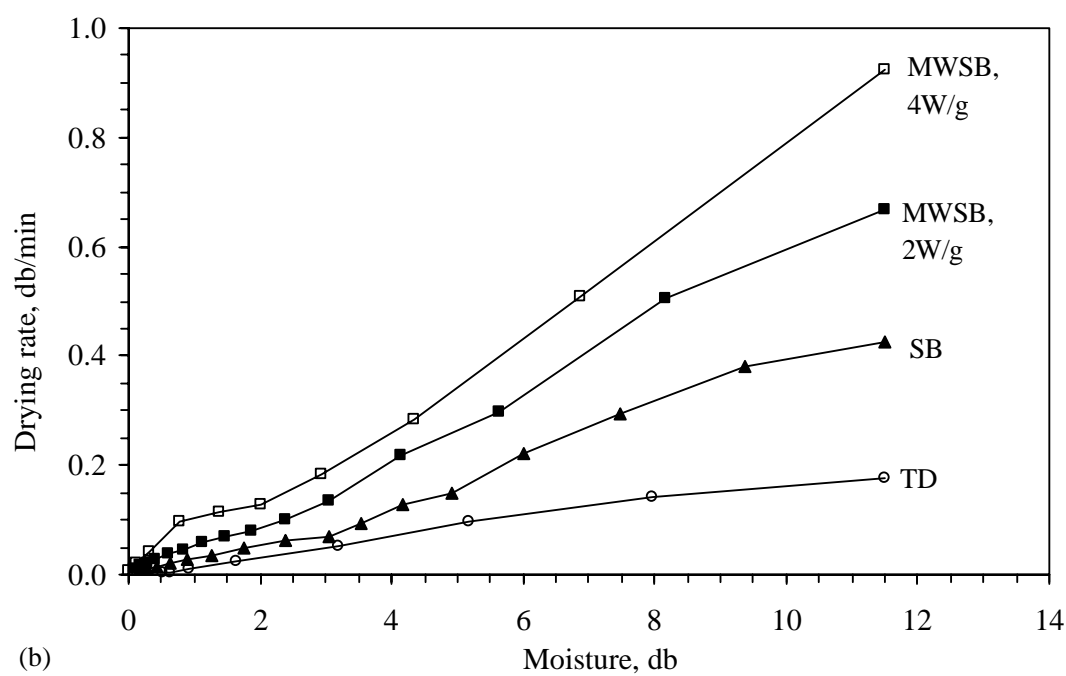

Fig. 3. Representative curves for microwave and spouted bed (MWSB), spouted bed (SB) and tray (TD) drying of asparagus slices at an air temperature of $60^{\circ} \mathrm{C}$ : (a) moisture loss curves and (b) drying rate curves. 
Table 1

Average drying rate of asparagus by five different drying methods

\begin{tabular}{llllc}
\hline Drying method & $\begin{array}{l}\text { MW power } \\
\text { level }(\mathrm{W} / \mathrm{g})^{\mathrm{a}}\end{array}$ & $\begin{array}{l}\text { Temp. } \\
\left({ }^{\circ} \mathrm{C}\right)\end{array}$ & $\begin{array}{l}\text { Hours to dry to } \\
\leqslant 0.1 \mathrm{MC}(\mathrm{db})\end{array}$ & $\begin{array}{l}\text { Drying rate } \\
(\% \mathrm{db} / \mathrm{min})\end{array}$ \\
\hline Freeze-drying & - & 20 & $18-24$ & $1.0-0.8$ \\
Tray drying & - & 50 & 5.5 & 3.4 \\
& & 60 & 3.5 & 5.3 \\
& & 70 & 2.5 & 10.4 \\
Spouted bed & 0 & 50 & 2.3 & 8.2 \\
& & 60 & 1.7 & 11.5 \\
& & 70 & 1.2 & 16.3 \\
MWSB & & & & 12.0 \\
& 2 & 50 & 1.6 & 19.1 \\
& & 60 & 1.0 & 22.9 \\
& & 70 & 0.8 & 32.1 \\
& 4 & 50 & 1.0 & 38.1 \\
& & 70 & 0.6 & 1301 \\
\hline
\end{tabular}

${ }^{\mathrm{a} W} / \mathrm{g}$ : Watts/g of fresh asparagus; RW: Refractance Window ${ }^{\mathrm{TM}}$. Under freeze-drying, time is for complete dryness and $20^{\circ} \mathrm{C}$ is the heating plate temperature.

the high rate of energy transfer into asparagus pieces and internal vapor pressure generated by the microwave field (Feng et al., 2001). Due to continuous mixing of particles and better heat and mass transfer at product surface, the SB drying is much faster than TD process.

The drying rate also increased with drying air temperature (Table 1). However, when asparagus was tray dried at $70^{\circ} \mathrm{C}$ we observed increasing darkening of the samples as drying progressed. TD of product at $50^{\circ} \mathrm{C}$ took the longest time. Among the drying methods in which hot air was used (i.e. tray, SB and MWSB drying), MWSB at a power level of $4 \mathrm{~W} / \mathrm{g}$ and a temperature of $70^{\circ} \mathrm{C}$ was the fastest (Table 1). High microwave power and high fluidized-bed temperature resulted in larger drying rates. While drying blueberries, Feng and Tang (1998) also found that combined MWSB drying is much faster than TD. But we noted some charring of the asparagus that was dried at a power level of $4 \mathrm{~W} / \mathrm{g}$. Therefore, the benefit of increased drying rate at higher microwave power densities may be reduced because of this charring. Compared to the darkening of product at $70^{\circ} \mathrm{C}$ air temperature and the charring observed at $4 \mathrm{~W} / \mathrm{g}$ of microwave power, good color was achieved at a lower temperature $\left(60^{\circ} \mathrm{C}\right)$ and a lower microwave power $(2 \mathrm{~W} / \mathrm{g})$.

The residence time for drying of $800 \mathrm{~g}$ of pureed asparagus from an average moisture content of 21.0 to $0.04 \mathrm{db}$ on the pilot scale RW system was $4.5 \mathrm{~min}$. Similar drying residence times for this system were obtained in a separate energy utilization study in which up to $145 \mathrm{~kg}$ of pumpkin puree was used as the starting material (Nindo, Feng, Shen, Tang, \& Kang, 2003). This fast drying is the result of high heat and mass transfer that takes place in the thin-film RW drying system. The continuous circulation of hot water below the thin conveyor belt $(\sim 0.2 \mathrm{~mm})$ and the thin spreading of puree on a large surface coupled with forced draft above the heated puree facilitated the drying process. As the puree dries, evaporative cooling takes place and prevents the puree from reaching the heating water temperature (Abonyi et al., 2002).

\subsection{Color and rehydration characteristics}

Among the drying methods studied, freeze-drying produced asparagus with the greatest lightness (L), greenness $\left(-\mathrm{a}^{*}\right)$, and yellowness $\left(+\mathrm{b}^{*}\right)$ compared to asparagus dried by the other four methods (Table 2 ). The RW-dried product was flaky and sheet-like with a bright green color, suggesting that most chlorophyll was retained in the process. Whole pureed asparagus that was dried by RW was closest in greenness to the freezedried product. Particles of asparagus tips that were tray dried at $60^{\circ} \mathrm{C}$ were the least green and had the lowest Lvalue (i.e. darkest). Asparagus tips that were tray dried at $60^{\circ} \mathrm{C}$ had the largest deviation $\left(\Delta E^{*}\right.$ value of 26.0$)$ from that of the fresh material, followed by MWSBdried whole asparagus and RW-dried products (Table 2). The color of freeze-dried asparagus deviated the least $\left(\Delta E^{*}\right.$ value of 9.6). The color data of freeze-dried (FD) asparagus is included here for comparison, because freeze-drying often produces the highest possible quality among all industrial drying methods.

Combined MWSB drying of asparagus slices also produced particles with good rehydration capacity (Table 3). Asparagus dried under combined MWSB at a power level of $4 \mathrm{~W} / \mathrm{g}$ had the highest rehydration ratio among the drying methods that used heated air. The investigation by Feng et al. (1999) also showed that blueberries dried in MWSB had very good rehydration characteristics. When the appearance of fresh, dried and rehydrated asparagus was measured, dried asparagus tended to become darker than the fresh asparagus. Rehydrated asparagus appears lighter and the greenness is reduced somewhat when compared to fresh asparagus (Fig. 4), but the product still looked excellent for use in instant soups.

\subsection{TAA and ascorbic acid content of dried asparagus}

The average TAA of the batch of raw material that was dried as whole spears was $65.7 \pm 5.2$ Trolox equivalents ( $\mu \mathrm{mol} / \mathrm{g}$ dried sample). Of the three drying methods involving the use of heated air and/or microwave energy, MWSB drying at a power level of $2 \mathrm{~W} / \mathrm{g}$ and at $60^{\circ} \mathrm{C}$ air temperature provided the highest retention of TAA (Table 4). All dried asparagus tended to lose some of their TAA as compared to the raw 
Table 2

Color parameters of asparagus dried by five different methods

\begin{tabular}{|c|c|c|c|c|c|c|c|c|}
\hline Drying method & Spear section & Drying time (h) & $\mathrm{Temp}^{\mathrm{a}}\left({ }^{\circ} \mathrm{C}\right)$ & $\mathrm{L}$ & $a^{*}$ & $b^{*}$ & Hue angle & $\Delta E^{*}$ \\
\hline \multirow[t]{3}{*}{ Tray drying } & Tips & 4 & 60 & $14.4 \pm 1.7$ & $-0.6 \pm 0.1$ & $12.2 \pm 1.0$ & 92.6 & 26.0 \\
\hline & Base & 5 & 50 & $24.8 \pm 2.1$ & $-2.6 \pm 0.7$ & $20.6 \pm 1.4$ & 92.7 & 17.9 \\
\hline & Base & 4 & 60 & $19.0 \pm 3.3$ & $-2.9 \pm 0.6$ & $16.1 \pm 2.2$ & 100.1 & 21.7 \\
\hline \multirow[t]{2}{*}{ Spouted bed } & Tips & 1.7 & 50 & $22.2 \pm 3.2$ & $-2.5 \pm 0.3$ & $14.3 \pm 1.7$ & 100.0 & 18.2 \\
\hline & Tips & 1.2 & 60 & $22.7 \pm 1.9$ & $-2.6 \pm 0.6$ & $12.8 \pm 0.7$ & 101.5 & 17.6 \\
\hline \multirow[t]{2}{*}{ MWSB } & Whole & 1.1 & 50 & $17.9 \pm 3.8$ & $-3.3 \pm 0.7$ & $14.7 \pm 3.2$ & 102.8 & 22.5 \\
\hline & Base & 1.2 & 60 & $26.8 \pm 2.0$ & $-1.9 \pm 0.5$ & $17.6 \pm 1.8$ & 96.1 & 14.8 \\
\hline RW & Whole & $<0.1$ & $95^{\mathrm{a}}$ & $18.3 \pm 3.4$ & $-4.5 \pm 0.4$ & $15.6 \pm 1.6$ & 106.0 & 22.4 \\
\hline Freeze-drying & Whole & $>12$ & $20^{\mathrm{b}}$ & $37.7 \pm 4.5$ & $-4.9 \pm 0.7$ & $20.7 \pm 1.4$ & 103.4 & 9.6 \\
\hline Raw material & - & - & - & $40.2 \pm 2.9$ & $-3.1 \pm 0.7$ & $11.7 \pm 2.6$ & 104.7 & - \\
\hline
\end{tabular}

${ }^{\mathrm{a}}$ Circulating water temperature.

${ }^{\mathrm{b}}$ Plate temperature. $\Delta E^{*}$ is calculated by using the color of raw material as reference.

Table 3

Rehydration ratio of asparagus after MW spouted bed, spouted bed, and tray drying

\begin{tabular}{|c|c|c|c|c|c|c|c|c|c|c|c|c|}
\hline \multirow[t]{2}{*}{ Soaking time (min) } & \multicolumn{4}{|l|}{$50^{\circ} \mathrm{C}$} & \multicolumn{4}{|l|}{$60^{\circ} \mathrm{C}$} & \multicolumn{4}{|l|}{$70^{\circ} \mathrm{C}$} \\
\hline & $4 \mathrm{~W} / \mathrm{g}$ & $2 \mathrm{~W} / \mathrm{g}$ & SB & $\mathrm{TD}$ & $4 \mathrm{~W} / \mathrm{g}$ & $2 \mathrm{~W} / \mathrm{g}$ & SB & TD & $4 \mathrm{~W} / \mathrm{g}$ & $2 \mathrm{~W} / \mathrm{g}$ & SB & $\mathrm{TD}$ \\
\hline 0 & 0.0 & 0.0 & 0.0 & 0.0 & 0.0 & 0.0 & 0.0 & 0.0 & 0.0 & 0.0 & 0.0 & 0.0 \\
\hline 5 & 1.4 & 1.2 & 0.8 & 0.9 & 1.3 & 1.3 & 1.0 & 1.4 & 1.5 & 1.3 & 1.3 & 1.0 \\
\hline 10 & 2.3 & 2.1 & 1.4 & 1.3 & 2.1 & 1.9 & 1.8 & 2.0 & 2.4 & 2.2 & 2.0 & 1.6 \\
\hline 15 & 3.1 & 2.7 & 2.1 & 1.9 & 2.7 & 2.5 & 2.5 & 2.7 & 3.1 & 2.9 & 2.7 & 2.4 \\
\hline 20 & 3.7 & 3.3 & 2.8 & 2.5 & 3.2 & 3.2 & 2.9 & 3.4 & 3.9 & 3.5 & 3.6 & 3.2 \\
\hline 30 & 4.9 & 4.3 & 4.0 & 3.5 & 4.0 & 4.1 & 3.6 & 4.3 & 4.8 & 4.4 & 4.5 & 4.4 \\
\hline
\end{tabular}

Units: grams of water absorbed per gram of dried asparagus.

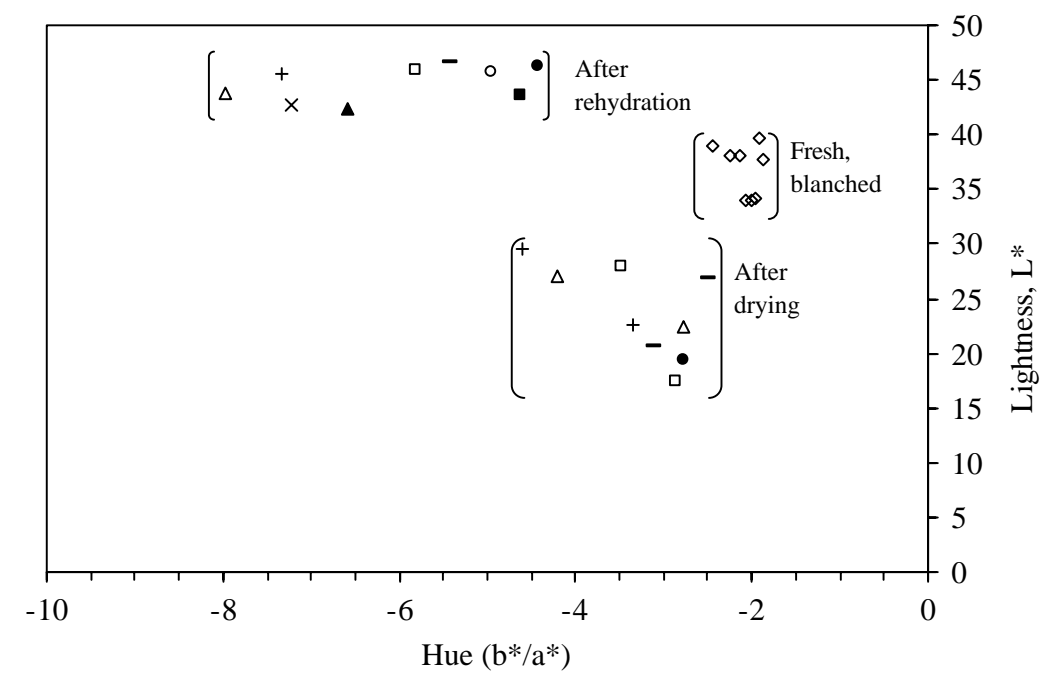

Fig. 4. Hue and lightness values for raw, dried and rehydrated asparagus. MWSB-dried asparagus (power level $(\mathrm{W} / \mathrm{g}) / \mathrm{temp} .\left({ }^{\circ} \mathrm{C}\right)$ ): $(\triangle) 4 / 70$;

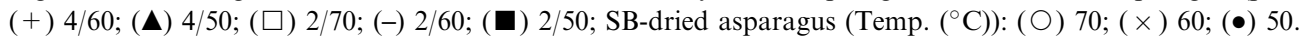

asparagus. In a second set of experiments in which the raw asparagus was cut into three portions (Table 5), the distribution of water-soluble antioxidant activity in the apical portion $(0-7 \mathrm{~cm})$, middle portion $(7-14 \mathrm{~cm})$, and basal portion $(14-21 \mathrm{~cm})$ was $65.5 \pm 2.1,50.1 \pm 3.5$, and $37.7 \pm 3.0$ Trolox equivalents $(\mu \mathrm{mol} / \mathrm{g}$, dry weight basis), respectively. If the high standard deviation for tip portion is taken into account, it can be seen that 
Table 4

Total antioxidant activity of tray dried, spouted bed and MWSB asparagus ${ }^{\mathrm{a}}$

\begin{tabular}{|c|c|c|c|c|}
\hline Drying method/condition & $\begin{array}{l}\text { Microwave power } \\
\text { level }(\mathrm{W} / \mathrm{g})\end{array}$ & Temp. $\left({ }^{\circ} \mathrm{C}\right)$ & $\begin{array}{l}\text { TAA (Trolox equiv.) } \\
(\mu \mathrm{mol} / \mathrm{g}, \text { dry basis })\end{array}$ & $\begin{array}{l}\text { Retained } \\
\text { TAA }(\%)\end{array}$ \\
\hline Raw material & - & - & $65.7 \pm 5.2$ & 100.0 \\
\hline \multirow[t]{3}{*}{ Tray drying } & \multirow[t]{3}{*}{0} & 50 & $48.1 \pm 1.8$ & 73.1 \\
\hline & & 60 & $47.6 \pm 1.4$ & 72.4 \\
\hline & & 70 & $46.9 \pm 2.9$ & 71.4 \\
\hline \multirow[t]{3}{*}{ Spouted bed } & \multirow[t]{3}{*}{0} & 50 & $40.5 \pm 2.9$ & 61.7 \\
\hline & & 60 & $52.0 \pm 4.1$ & 79.2 \\
\hline & & 70 & $39.2 \pm 2.9$ & 59.7 \\
\hline \multirow[t]{6}{*}{ Microwave and spouted bed } & \multirow[t]{3}{*}{2} & 50 & $42.6 \pm 1.5$ & 64.8 \\
\hline & & 60 & $53.5 \pm 3.3$ & 81.4 \\
\hline & & 70 & $45.6 \pm 1.6$ & 69.4 \\
\hline & \multirow[t]{3}{*}{4} & 50 & $46.2 \pm 2.2$ & 70.3 \\
\hline & & 60 & $49.9 \pm 1.1$ & 75.9 \\
\hline & & 70 & $42.0 \pm 1.6$ & 63.9 \\
\hline
\end{tabular}

${ }^{\mathrm{a}}$ The three listed drying methods are the ones that involved the use of heated air. The TAA values are for whole asparagus spears.

Table 5

Effect of drying method on TAA of tip, middle and basal portions of green asparagus

\begin{tabular}{lllllll}
\hline Drying treatment & $\begin{array}{l}\text { MW power } \\
(\mathrm{W} / \mathrm{g})\end{array}$ & $\begin{array}{l}\text { Temp. } \\
\left({ }^{\circ} \mathrm{C}\right)\end{array}$ & $\begin{array}{l}\text { Tip } \\
\text { portion }\end{array}$ & $\begin{array}{l}\text { Middle } \\
\text { portion }\end{array}$ & $\begin{array}{l}\text { Basal } \\
\text { portion }\end{array}$ \\
\hline Raw material & - & NA & $65.5 \pm 2.1$ & $50.1 \pm 3.5$ & $37.7 \pm 3.0$ \\
Freeze-drying & - & 20 (plate) & $98.4 \pm 3.7 \mathrm{a}$ & $74.5 \pm 4.1 \mathrm{a}$ & $55.7 \pm 3.5 \mathrm{a}$ & $76.2 \pm 2.9$ \\
spear
\end{tabular}

\footnotetext{
${ }^{a}$ Tukey's HSD test. Same letter in the same column means there is no difference between treatments. Units of TAA are in Trolox equiv., $\mu \mathrm{mol} / \mathrm{g}$
} (dry weight basis).

Refractance Window ${ }^{\mathrm{TM}}$ drying method resulted in the maximum TAA in all the three portions. However, after carrying out Tukey's HSD test, the retention of TAA after RW and freeze-drying was not significantly different. On examining the effect of drying method on retention of TAA in three different portions of blanched asparagus, both RW and freeze-drying which rely on different heating mechanisms showed enhanced TAA than the drying methods where heated air was used. Heated air inherently exposes the products to oxidation, thus reducing their TAA. In the RW drying process, the pureed product heats up very fast. This caused increased release of phenolic compounds bound in the cell matrix. Moisture loss is very intensive during the first $1 \mathrm{~min}$ of drying, and the partial pressure of oxygen near the product becomes very low due to the high local vapor pressure created by moisture evaporation (Abonyi et al., 2002). This condition prevented the oxidation of phenolic antioxidants in asparagus that were made more available by the heating process. It has recently been shown that thermal processing of sweet corn caused antioxidant activity and total phenolics to increase by $44 \%$ and $54 \%$, respectively, although $25 \%$ loss of ascorbic acid was observed (Dewanto, Wu, Adom, \& Liu, 2002). Other related studies on thermally processed tomatoes, tomato juice and other products have shown that heating caused an increase in their overall antioxidant potential due to production of nonnutrient antioxidants (Nicoli et al., 1997; Anese et al., 1999a; Dewanto, Wu, \& Liu, 2002). Nicoli et al. (1997) concluded that although natural antioxidants are lost during heating, the overall antioxidant properties of foods could be maintained or enhanced by the development of new antioxidants.

The retention of ascorbic acid was highest in RW drying, followed by freeze-drying, MWSB drying, SB drying, and was least in TD (Fig. 5). After TD, less ascorbic acid was retained in the tips than in the middle 


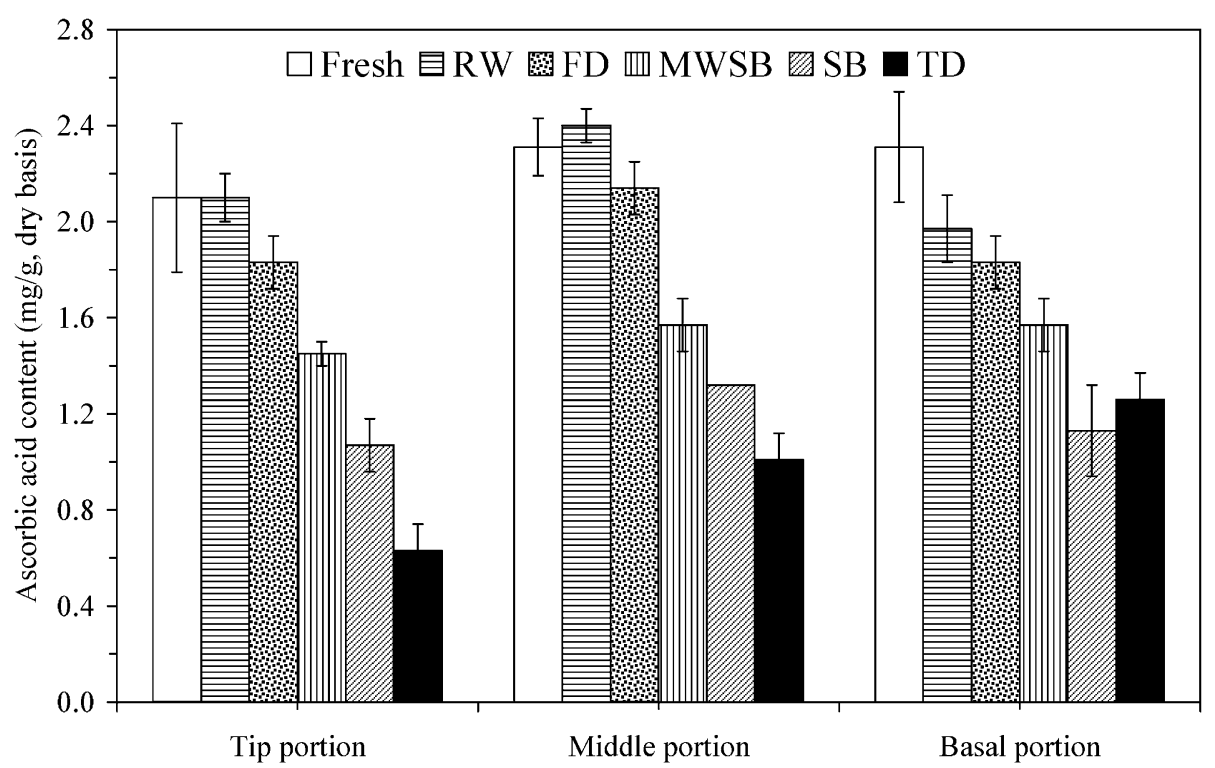

Fig. 5. Ascorbic acid content of three portions of asparagus spear after microwave spouted bed drying (MWSB), spouted bed drying (SB), and tray drying (TD) at $60^{\circ} \mathrm{C}$. Power level for MWSB is $2 \mathrm{~W} / \mathrm{g}$.

and basal parts. In absolute terms, the middle and basal parts contained more ascorbic acid than the tip portion of asparagus. Using ascorbic retention as an index for comparison, the RW-dried product is almost indistinguishable from the raw material. This result corroborates the findings of Abonyi et al. (2002) who reported only $6 \%$ loss of ascorbic acid (AA) in strawberry puree and $9.9 \%$ loss of $\beta$-carotene in carrot puree after RW drying. They attributed the low loss of AA and $\beta$ carotene to the unique moisture loss characteristics (and the more moderate time-temperature combination) associated with RW drying technology. According to Jayaraman and Gupta (1995), slow drying methods like sun drying cause increased loss of ascorbic acid (AA). Freeze-drying resulted in lower retention of ascorbic acid for the tip and middle portion of asparagus compared to RW drying. This may be due to the long drying time (18-24 h) and the large surface area or openpore structure of the dried asparagus that facilitates oxidation of ascorbic acid. The combination of short drying times (less than $5 \mathrm{~min}$ ) and product temperatures between $70^{\circ} \mathrm{C}$ and $80^{\circ} \mathrm{C}$ during $\mathrm{RW}$ drying is important for retention of nutritional quality of dried asparagus.

\section{Conclusion}

Combined microwave and spouted bed drying of asparagus slices at a power level of $4 \mathrm{~W} / \mathrm{g}$ was at least 5 times faster than tray drying when air temperatures between $50^{\circ} \mathrm{C}$ and $70^{\circ} \mathrm{C}$ were used. At a drying air temperature of $60^{\circ} \mathrm{C}$, the MWSB drying rate at $4 \mathrm{~W} / \mathrm{g}$ power level was $6.0,2.8$, and 1.7 times faster than tray, spouted bed and MWSB drying at the $2 \mathrm{~W} / \mathrm{g}$ level, respectively. However, the $4 \mathrm{~W} / \mathrm{g}$ power level caused some charring of the product. The reconstituted dried asparagus was lighter in color with a hue angle greater than both the fresh and the dried counterparts. MWSB-dried asparagus had the highest rehydration ratio after $30 \mathrm{~min}$ in $70^{\circ} \mathrm{C}$ water. TAA of asparagus after RW and freeze-drying was significantly higher than after tray drying, spouted bed and combined microwave spouted bed drying. In all cases, the tip portion retained more TAA after drying than either middle or basal parts. Among the methods involving the use of heated air, microwave spouted bed drying at $2 \mathrm{~W} / \mathrm{g}$ and $60^{\circ} \mathrm{C}$ resulted in highest retention of TAA in asparagus. RW drying method resulted in the highest retention of ascorbic acid in asparagus as compared to all the other drying methods studied. These results are useful for evaluating the effect of the selected drying methods on TAA and ascorbic acid and not necessarily for making a choice of particular process over another.

\section{Acknowledgements}

We thank the USDA Cooperative State Research, Education and Extension Service (CSREES) for providing the grant without which this research would not have been conducted. Special thanks to Richard E. Magoon and Karin M. Bolland of MCD Technologies, Inc. (Tacoma, WA) for their assistance with the RW drying experiment. 


\section{References}

Abonyi, B. I., Feng, H., Tang, J., Edwards, C. G., Mattinson, D. S., \& Fellman, J. K. (2002). Quality retention in strawberry and carrot purees dried with Refractance Window ${ }^{\mathrm{TM}}$ System. Journal of Food Science, 67, 1051-1056.

Anese, M., Manzocco, L., Nicoli, M. C., \& Lerici, C. R. (1999a). Antioxidant properties of tomato juice as affected by heating. Journal of the Science of Food and Agriculture, 79, 750-754.

Anese, M., Nicoli, M. C., Massini, R., \& Lerici, C. R. (1999b). Effects of drying processing on the Maillard reaction in pasta. Food Research International, 32, 193-199.

AOAC. (1995). Official methods of analysis (16th ed.). Washington, DC: Association of Official Analytical Chemists.

Brennan, J. G., Butters, J. R., Cowell, N. D., \& Lilly, A. E. V. (1990). Dehydration in food engineering operations (3rd ed.) (pp. 371-415). London: Elsevier Applied Science.

Calvin, L., \& Cook, R. (1997). Exporters target US asparagus market. USDA Economic Research Service. Agricultural Outlook, April, 20-23.

Cano, A., Hernández-Ruíz, J., García-Cárnovas, F., Acosta, M., \& Arnao, M. B. (1998). An end point method for estimation of the total antioxidant activity in plant material. Phytochemical Analysis, 9, 196-202.

Dewanto, V., Wu, X., \& Liu, R. H. (2002). Processed sweet corn has higher antioxidant activity. Journal of Agricultural and Food Chemistry, 50, 4959-4964.

Esteve, M. J., Frigola, A., Martoreli, L., \& Rodrigo, C. (1998). Kinetics of ascorbic acid degradation in green asparagus during heat processing. Journal of Food Protection, 61, 1518-1521.

Feng, H., \& Tang, J. (1998). Microwave finish drying of diced apples in a spouted bed. Journal of Food Science, 63, 679-683.

Feng, H., Tang, J., Cavalieri, R. P., \& Plump, O. A. (2001). Heat and mass transport in microwave drying of porous materials in a spouted bed. American Institute Chemical Engineers Journal, 47, $1499-1511$.

Feng, H., Tang, J., Mattinson, D. S., \& Fellman, J. K. (1999). Microwave and spouted bed drying of frozen blueberries: The effect of drying and pretreatment methods on physical properties and retention of flavor volatiles. Journal of Food Processing and Preservation, 23, 463-479.

Jayaraman, K. S., \& Gupta, D. K. D. (1995). Drying of fruits and vegetables. In A. S. Mujumdar (Ed.), Handbook of industrial drying (p. 669). New York: Marcel Dekker, Inc.

Krokida, M. K., Maroulis, Z. B., \& Saravakos, G. D. (2001). The effect of the method of drying on the color of dehydrated products. International Journal of Food Science and Technology, 36, 53-59.
Lau, M. H., Tang, J., \& Swanson, B. G. (2000). Kinetics of textural and color changes in green asparagus during thermal treatments. Journal of Food Engineering, 45, 231-236.

Makris, D. P., \& Rossiter, J. T. (2001). Domestic processing of onion bulbs (Allium cepa) and asparagus spears (Asparagus officinalis): Effect of flavonol content and antioxidant status. Journal of Agricultural and Food Chemistry, 49, 3216-3222.

Maskan, M. (2000). Microwave/air and microwave finish drying of banana. Journal of Food Engineering, 44, 71-78.

Miller, N. J., Diplock, A. T., \& Rice-evans, C. A. (1995). Evaluation of the total antioxidant activity as a marker of the deterioration of apple juice on storage. Journal of Agricultural and Food Chemistry, 43, 1794-1801.

Nicoli, M. C., Anese, M., Parpinel, M. T., Franceschi, S., \& Lerici, C. R. (1997). Loss and/or formation of antioxidants during food processing and storage. Cancer Letters, 114, 71-74.

Nijhuis, H. H., Torringa, H. M., Muresan, S., Yuksel, D., Leguijt, C., \& Kloek, W. (1998). Approaches to improving the quality of dried fruit and vegetables. Trends Food Science and Technology, 9, 13-20.

Nindo, C. I., Feng, H., Shen, G. Q., Tang, J., \& Kang, D. H. (2003). Energy utilization and microbial reduction in a new film drying system. Journal of Food Processing and Preservation, in press.

Pokorny, J., \& Schmidt, S. (2001). Natural antioxidant functionality during food processing. In J. Pokorny, N. Yanishlieva, \& M. Gordon (Eds.), Antioxidants in foods (pp. 331-354). Boca Raton, FL: CRC Press LLC.

Somogyi, L. P., \& Luh, B. S. (1986). Vegetable dehydration. In J. G. Woodroof, \& B. S. Luh (Eds.), Commercial fruit processing (p. 435). Westport, CT: AVI Publishing Co.

Strahm, B. S., \& Flores, R. A. (1994). Dehydration of low-grade asparagus. Drying Technology, 12, 903-921.

Strahm, B. S., Flores, R. A., \& Chung, D. S. (1995). Properties of dehydrated of low-grade asparagus. Journal of Food Protection, 58 , 804-809.

Torringa, E. M, Van Dijk, E. J., \& Bartels, P. V. (1996). Microwave puffing of vegetables: Modeling and measurements. Proceedings of 31st microwave power symposium, Park Plaza Hotel, Boston, MA, July 28-31 (pp. 16-19).

USGAO. (2001). Agricultural trade: Impacts of the Andean Trade Preference Act on asparagus producers and consumers. Report No. GAO-01-315, United States General Accounting Office, Washington, DC.

Vinson, J. A., Hao, Y., Su, X., \& Zubik, L. (1998). Phenol antioxidant quantity and quality in foods: Vegetables. Journal of Agricultural and Food Chemistry, 46, 3630-3634.

Yanishlieva-maslarova, N. V. (2001). Inhibiting oxidation. In J. Pokorny, N. Yanishlieva, \& M. Gordon (Eds.), Antioxidants in foods (pp. 22-70). Boca Raton, FL: CRC Press LLC. 